\title{
Sulphate Induced Strength Loss Index Optimisation of Periwinkle and Clam Shell Ash Hybrid Pozzolana Concrete
}

\author{
H.D. Mac-Eteli and K. E. Overo \\ ${ }^{1}$ Department of Civil Engineering \\ Niger Delta University \\ Bayelsa State, Nigeria
}

\begin{abstract}
The globe yearns for sustainability in meeting the present and future needs of man. Hence, research into more sustainable mode of harvesting, processing and use of nature's raw resources is evidently timely. Cement replacement is opined on the need to reduce the environmental as well as economical limitations associated with its production, while been configured to allow for adequate strength and durability. This paper study the mechanical behaviour of ternary blended cement composed of Portland limestone cement, calcined periwinkle and clam shell ashes in concrete exposed to a sulphated medium. Combined I-optimal mixture design was used to statistically develop and diagnose models from laboratory-analysed data and used to optimize calcination temperature and synergistic ratio, as well as the compressive strength and sulphate induced strength loss index (SISLI). For a constant sulphate medium of $5 \%$ sodium sulphate solution, the volatile calcination temperature range $\left(25^{\circ} \mathrm{C}-\right.$ $\left.200^{\circ} \mathrm{C}\right)$ was separated from the placid $\left(335^{\circ} \mathrm{C}-800^{\circ} \mathrm{C}\right)$ during optimization. In comparison to a 28-day control SISLI of $16.47 \%$, the optimal calcination temperature for SISLI was restricted at $606.7^{\circ} \mathrm{C}$, yielding a respective SISLI of $-0.078 \%$. With respect to synergistic ratio, developed model suggests that Increasing the concentration of clam shell ash lowers the calcination temperature needed to improve concrete's resistance to sulphate attack, however a balance needed for other mechanical and durability variables provided a ternary configuration of 54.6\%PLC:25.1\%PSA:20.3\%CSA at a calcination temperature of $606.7 \%$. Developed model can hence be integrated into the engineering society in decision making and policies associated with the adequate use of periwinkle and clam shell ashes as components of a ternary blended cement in concrete exposed to a sulphated environment.
\end{abstract}

Key Words: SISLI, Compressive strength, Pozzolana Concrete, Calcination Temperature, Synergistic Ratio.

\subsection{INTRODUCTION}

The construction industry is embodied with the responsibility to look at employing by-products and waste materials for construction due to growing concerns about the earth's natural resources depletion and global pollution and this is the primary objective driving many research works geared towards the use waste materials in the cement manufacturing process $[1,2]$

In the hardened condition, one of the most essential features of concrete is its compressive strength. The resistance to compressive loads is the primary consideration in the construction of concrete structures and as such, compressive strength is the quality criterion in structural design $[3,4]$. Concrete's compressive strength and service life, on the other hand, may be hampered by its exposed state. As such, it is expected that concrete produced at any given time will perform satisfactorily in compressive strength requirements as well as in the environment in which the structure is positioned, among other features [3]. The durability of concrete which is its ability to withstand weathering, chemical attack, abrasion, or any other degrading process is either externally or internally engaged. Whilst internal forces are depended on the soundness of the components of concrete, external forces are primarily the exposed conditions of the concrete during and after the hydration as well as over the design life of the concrete.

Clam shells and periwinkle shells are calcareous sea shells with high calcium concentration and can help to improve the mechanical and durability qualities of concrete [5]. The effects of sulphates on concrete include a loss of strength, expansion, surface spalling, mass loss, and eventual disintegration [6]. Other researchers such as [11 and 12] further asserted that sulphates, either endogenously or exogenously injected, have been linked to a decrease in the compressive strength of mortar and concrete. Sulphate attack mechanism has been studied in-depth [7,8,9 and 10], and in summary suggests that the presence of tricalcium aluminate (C3A, compound in cement responsible for the earliest strength development) and calcium hydroxide $(\mathrm{CaOH}$, a byproduct from the hydration of cement) are responsible for the formation of expansive calcium sulphur-aluminates (ettringite) in an 
endogenous or exogenous sulphated media. Formation of expansive ettringite leads to the spalling of the concrete surface as well as results in the inducement of internal stresses in the concrete which forms a network of cracks on the surface of the concrete structure as shown in Fig. 1.

It is quite noteworthy that a drive towards a sulphate resistant concrete will require a binder with reduced $\mathrm{C} 3 \mathrm{~A}$ and $\mathrm{CaOH}$ formation. Mineral admixtures such as crushed granulated blast furnace slag, fly ash, silica fume, rice husk ash, and metakaolin are mixed with cement or lime to make concrete more resistant to sulphate attack [3]. Pozzolanic reaction involves consuming the calcium hydroxide and the dilution of the calcium aluminates hydrates phase due to a reduction in the amount of plain cement in the total binder, and this is responsible for blended cement's enhanced performance over plain cement concrete in a sulphated environment $[13,14]$.

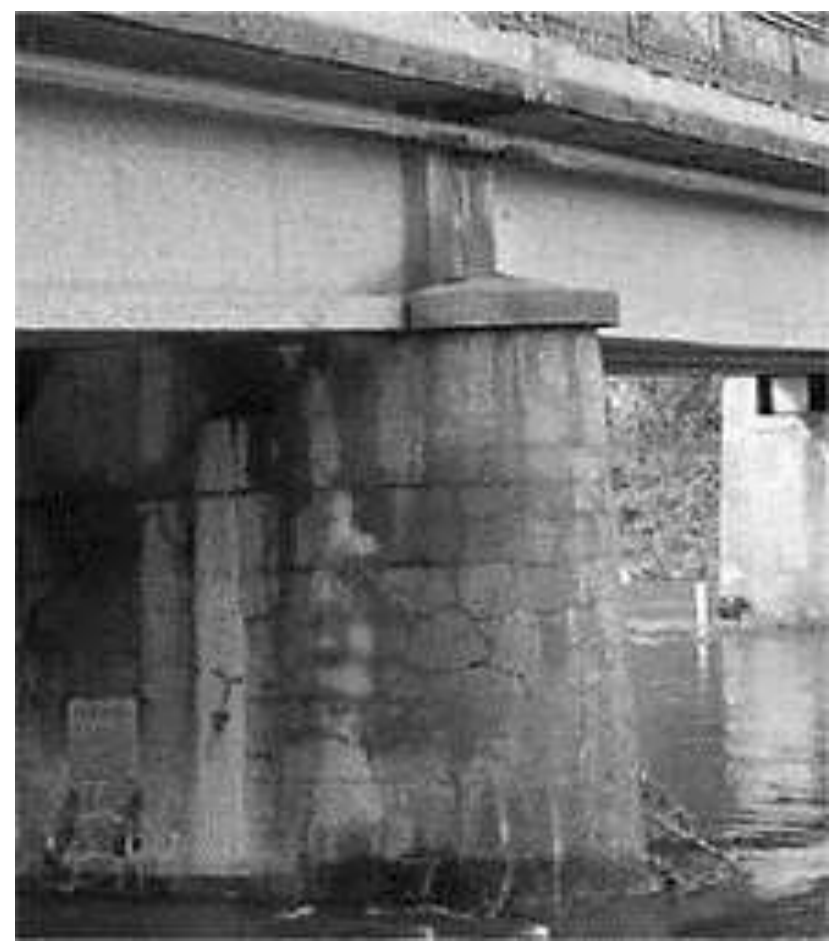

Fig.1 Cracking pattern in a bridge suffering from endogenous sulphate attack [9].

In recent years, there has been an increasing interest in using agricultural wastes as mineral admixtures to improve the characteristics of concrete and soil $[1,3,15,16]$. This is partly intended to revalue the agricultural sector by valuing the byproducts of its primary production process as well as meet the social need of job creation and diversification. [3] varied the concentrations of PSA as well as the concentration of magnesium sulphate (MgSO4) and reported findings favouring the presence of PSA at $10 \%$ cement replacement level. Similarly, [1] investigated the effect of varying concentrations of seashells on the concrete's resistance to alkaline and sulphate attack. They contributed by adding that at 5\% seashell concentration, compressive strength loss recorded was better than that of plain concrete. [17] rice husk ash (RHA) pozzolana concrete is effective against sulphate attack at concentrations below 30\%, proving better sulphate resistance to plain concrete, however with respect to compressive strength, RHA concentration of $7.5 \%$ was recommended.

This research is novel as it is practically premier in the context of monitoring the combined effect of calcination temperature and synergistic ratio (between periwinkle shell and clam shell ash) on the sulphate induced strength loss index, in a bid to produce an optimised ternary blended cement with a self-cementing potential with improved cement replaceability whilst maintaining good mechanical and durability indices.

\subsection{MATERIALS AND METHODS}

Shells of periwinkles and clams were collected from the area surrounding the main market in Amassoma, Bayelsa state. To eliminate organic matter and moisture, samples were washed and sun dried for 48 hours. Following that, samples were broken down with a hammer mill, synergised interchangeably at varying synergistic ratio ranging from (30\% - 70\%) and samples with a micron size smaller than 600 were prepared for calcination. Calcination was carefully monitored in the absence of oxygen, at a rate of about $10^{\circ} \mathrm{C}$ per minute, with an extra 30 minutes for homogeneity and finally pulverised to achieve a fineness of more than $50 \%$ passing 90 micron sieve. 
International Journal of Advances in Scientific Research and Engineering (ijasre), Vol 7 (8), August -2021

Table 1: Tests Methods

\begin{tabular}{|c|c|c|c|c|c|c|c|c|}
\hline $\mathbf{S} / \mathbf{N}$ & Test Method & $\begin{array}{l}\text { Test } \\
\text { standard }\end{array}$ & Synergy & $\begin{array}{l}\text { Replc. } \\
\text { Level }\end{array}$ & $\begin{array}{l}\text { Temp. } \\
\text { Level }\end{array}$ & $\begin{array}{l}\text { Spec. } \\
\text { per } \\
\text { age }\end{array}$ & $\begin{array}{l}\text { Control } \\
\text { spec. }\end{array}$ & $\begin{array}{l}\text { Total } \\
\text { Spec. }\end{array}$ \\
\hline & & & $\mathbf{A}$ & B & C & $\mathbf{E}$ & $\mathbf{F}$ & $\begin{array}{l}\left(\mathbf{A}^{*} \mathbf{B} * \mathbf{C}^{*}\right. \\
\mathbf{E})+\mathbf{F}\end{array}$ \\
\hline 1 & $\begin{array}{l}\text { Particle Size } \\
\text { Distribution for } \\
\text { Fine Aggregate }\end{array}$ & [18] & - & - & - & - & - & - \\
\hline 2 & $\begin{array}{l}\text { Particle Size } \\
\text { Distribution for } \\
\text { Coarse Aggregate }\end{array}$ & [18] & - & - & - & - & - & - \\
\hline 3 & Fineness Test* & [19], [20] & 7 & - & 5 & - & 1 & 36 \\
\hline 4 & Specific Gravity & {$[21]$} & 7 & - & 5 & - & 1 & 36 \\
\hline 5 & $\begin{array}{l}\text { Water } \\
\text { Demand/Slump/ } \\
\text { Workability }\end{array}$ & [22] & - & - & - & - & - & - \\
\hline 6 & $\begin{array}{l}\text { Compressive } \\
\text { Strength }\end{array}$ & [23] & 7 & 4 & 5 & 3 & 9 & 429 \\
\hline 7 & SISLI & [1], [3] & 7 & 4 & 5 & 3 & 9 & 429 \\
\hline
\end{tabular}

This study used the typical concrete materials of Portland cement, fine aggregate (sand), coarse aggregate (granite), and water. Primary and hybrid pozzolanic materials were used to group additional agricultural waste elements.

The investigation's major research materials were categorized as agricultural pozzolans (AP). Clam shell ash (CSA) and Periwinkle shell ash (PSA) are two of them. The main materials were created at five (5) different temperatures: ambient temperature $\left(25^{\circ} \mathrm{C}\right), 200^{\circ} \mathrm{C}, 400^{\circ} \mathrm{C}, 600^{\circ} \mathrm{C}$, and $800^{\circ} \mathrm{C}$. As a result, a total of twenty (20) primary samples were created for this study and used to substitute cement at five different levels: $0 \%, 20 \%, 30 \%, 40 \%$, and $50 \%$.

The hybrid research materials were created through the synergistic creation of five (5) sets of hybrid materials with complementary calcium and silicon oxides. Mass proportioning in the ratios of 70:30, 60:40, 50:50, 40:60, and 30:70 was used to create the hybrids. These were calcined at five (5) different temperatures: $25^{\circ} \mathrm{C}, 200^{\circ} \mathrm{C}, 400^{\circ} \mathrm{C}, 600^{\circ} \mathrm{C}$, and $800^{\circ} \mathrm{C}$. As a result, a total of 25 hybrid samples were created as part of this study's hybrid research samples and used to partially replace cement in concrete at the same amounts as the parent components.

\section{RESULTS}

\subsection{Particle size distribution of fine and coarse aggregate}

Fig. 2 represents the particle size distribution of the fine aggregate which shows that the fine aggregate (river sand) used for the experimental study, falls under Zone 3 this class of sand alongside zone 2 are suitable for concrete works [24]. The coarse aggregate utilized in this experiment has a particle size distribution ranging from $4.75 \mathrm{~mm}$ to $19.1 \mathrm{~mm}$. This is an illustration of a well-graded coarse aggregate that is suitable for use in concrete production. 


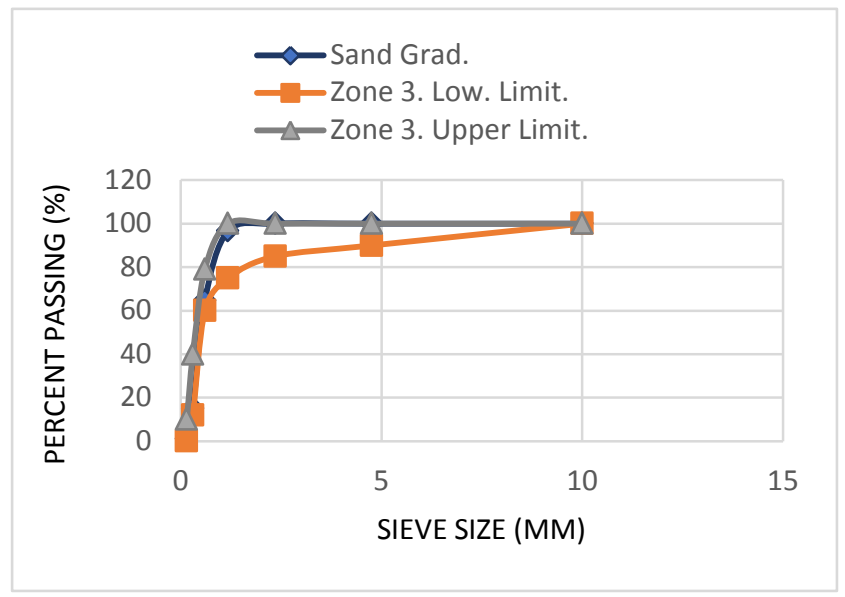

A

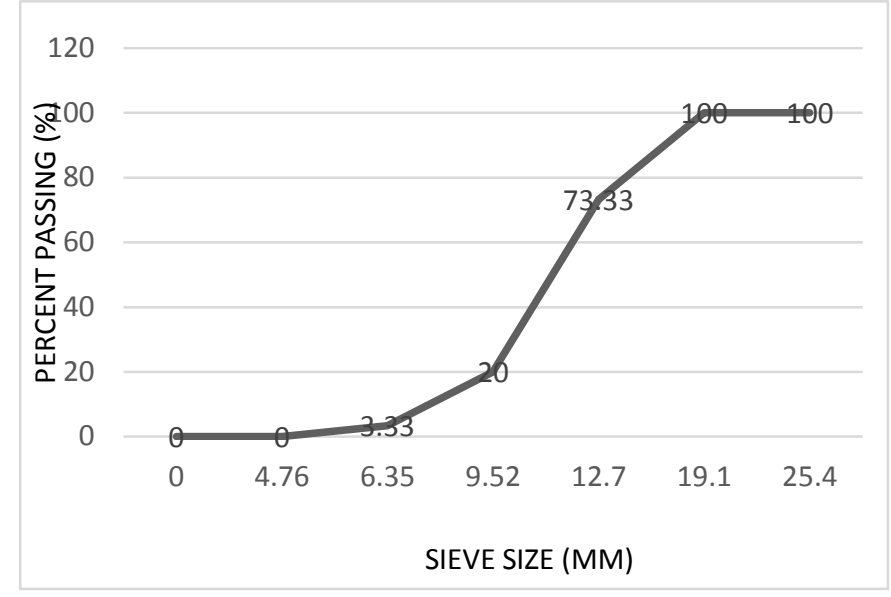

B

Fig. 2 Particle size distribution of the fine aggregate (A) and Coarse aggregates (B)

Table 2: Specific gravity of samples

\begin{tabular}{llllll}
\hline Temperature & $\mathbf{2 5}^{\mathbf{C}} \mathbf{C}$ & $\mathbf{2 0 0}^{\mathbf{C}} \mathbf{C}$ & $\mathbf{4 0 0}^{\mathbf{}} \mathbf{C}$ & $\mathbf{6 0 0}^{\mathbf{}} \mathbf{C}$ & $\mathbf{8 0 0}^{\mathbf{C}} \mathbf{C}$ \\
\hline CONTROL & 3.13 & & & & \\
PSA & 2.66 & 2.78 & 2.96 & 2.96 & 2.85 \\
70PSA & 2.94 & 3.05 & 3.12 & 3.12 & 2.94 \\
60PSA & 3.12 & 3.12 & 3.14 & 3.12 & 2.94 \\
50PSA & 3.12 & 3.12 & 3.12 & 3.12 & 2.78 \\
40PSA & 3.12 & 3.12 & 3.12 & 3.12 & 2.63 \\
30PSA & 3.12 & 3.12 & 3.12 & 3.12 & 2.78 \\
CSA & 2.94 & 2.94 & 2.98 & 3.00 & 2.78 \\
\hline
\end{tabular}

\subsection{Specific Gravity}

The combined effect of calcination temperature and synergistic ratio on the specific gravity of PSA/CSA hybrid pozzolan is depicted in Table 2. Except at $800^{\circ} \mathrm{C}$, where a reduction in trend was seen, calcination had very little bearing on specific gravity for AP materials. Calcination temperatures between $400^{\circ} \mathrm{C}$ and $600^{\circ} \mathrm{C}$ produced the best specific gravities for the five synergies investigated. However, $60 \mathrm{P}$ at $400^{\circ} \mathrm{C}$, with a specific gravity of 3.14 , had the highest recorded specific gravity among the sample size, and it was found to be 0.32 percent higher than the control's specific gravity of 3.13 . As a result, all synergies at temperatures between $400^{\circ} \mathrm{C}$ and $800^{\circ} \mathrm{C}$ have strong hydraulic characteristics under the right fineness and would require an adequate water/binder ratio.

It's worth noting that the specific gravity of a substance is proportional to how much heavier it is than water. In simple terms, the substance with a bigger volume will have a lower specific gravity at constant mass. In the context of this study, materials with a lower specific gravity have larger volumes than their counterparts, necessitating a greater water/binder ratio to achieve hydraulicity, which reduces concrete strength. While fineness was optimum at $800^{\circ} \mathrm{C}$ as shown in Fig.3., specific gravity declined substantially at the same temperature. 


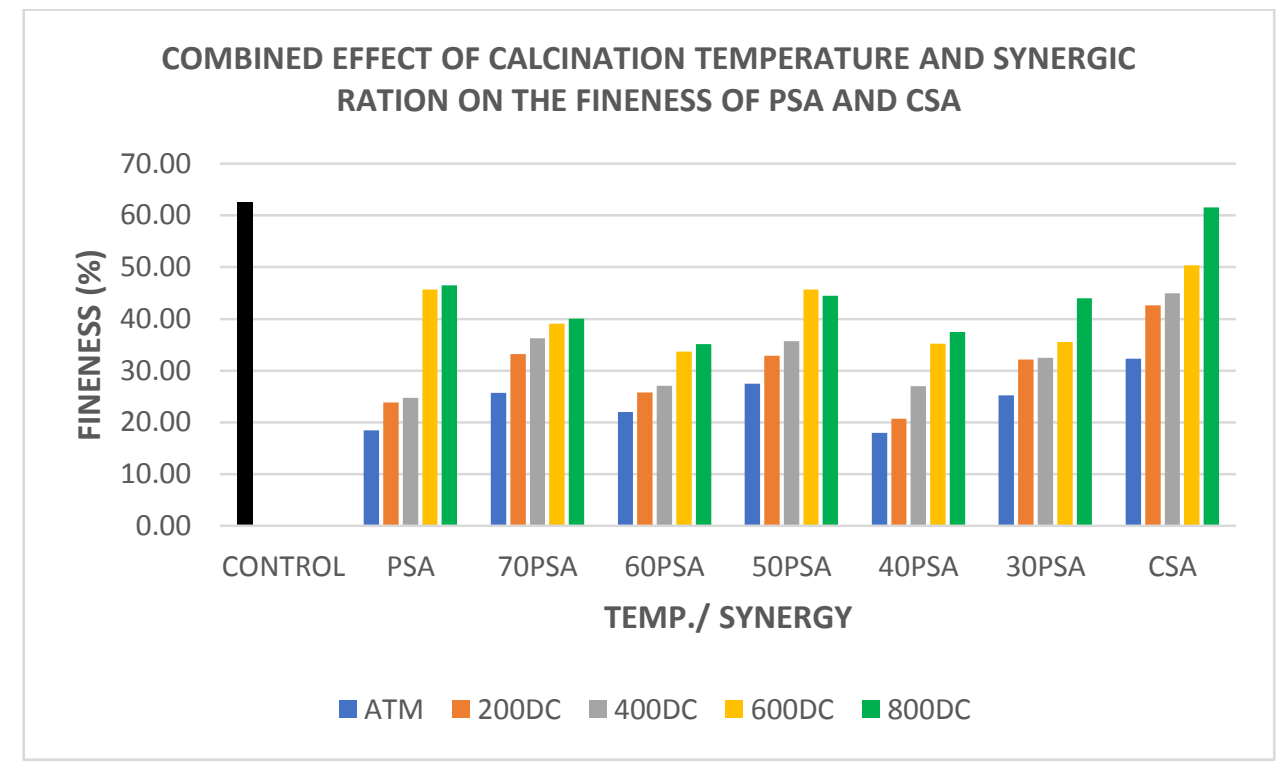

Fig. 3: Combined effect of calcination and synergistic ratio on the fineness of PSA/CSA hybrid pozzolan

\subsection{Fineness}

Fig. 3., depicts the combined influence of calcination temperature and synergistic ratio on the fineness of hybrid PSA/CSA samples. According to the findings, raising the calcination temperature increases fineness. Bonds grow and break at higher temperatures, resulting in monolithic materials, which is scientifically logical. With the exception of 50P, all synergies have an optimum temperature of $800^{\circ} \mathrm{C}$. In terms of synergy, it was observed that there was a near-direct relationship between CSA content and fineness, however it was not totally linear. Fineness was found to improve with a higher CSA concentration. At $800^{\circ} \mathrm{C}$, the best fineness result was $100 \%$ CSA, with 61.57 percent passing the 90 -micron sieve, compared to 98.5 percent for the control binder (Portland Limestone Cement), which had a fineness of 62.5 percent passing the 90 -micron sieve.

\subsection{Water Demand/ Slump}

The combined influence of calcination temperature and synergistic ratio on the slump properties of PSA/CSA pozzolana concrete with a 50\% cement replacement level is as shown in Table 3. In terms of calcination temperature, the significant tendency is that the slump grows as the temperature rises. A pattern approximating a cubic connection arises in terms of synergistic ratio, with a crest of $60 \mathrm{P}$ and a trough of $40 \mathrm{P}$ and $30 \mathrm{P}$. This is the earliest indication of the hydraulic properties of wet concrete in the plastic state, illustrating that as PSA declines up to 60P, concrete water demand decreases, then increasing between $60 \mathrm{P}$ and $40 \mathrm{P}$, and finally reducing between 40P and 100CSA. At 60P, the optimal slump of 190mm was around 141 percent of the control slump of $135 \mathrm{~mm}$. It's worth noting that the water-to-binder ratio is directly proportional to slump and indirectly proportional to water demand. In this setting, slump is indirectly proportional to water consumption and directly proportional to concrete strength at constant water to binder ratios, as was the case in this study.

Table 3. Slump of PSA/CSA pozzolana concrete at $50 \%$ cement replacement level

\begin{tabular}{lccccc}
\hline Temperature & $\mathbf{2 5}^{\mathbf{C}} \mathbf{C}$ & $\mathbf{2 0 0}^{\mathbf{0}} \mathbf{C}$ & $\mathbf{4 0 0}^{\mathbf{O}} \mathbf{C}$ & $\mathbf{6 0 0}^{\mathbf{}} \mathbf{C}$ & $\mathbf{8 0 0}^{\mathbf{}} \mathbf{C}$ \\
\hline Control & 135 & & & & \\
PSA & 52 & 68 & 98 & 125 & 105 \\
70 P & 65 & 82 & 120 & 150 & 111 \\
$60 P$ & 82 & 113 & 135 & 165 & 126 \\
50P & 87 & 93 & 119 & 150 & 112 \\
40P & 74 & 80 & 103 & 134 & 70 \\
30P & 74 & 87 & 95 & 123 & 75 \\
CSA & 85 & 120 & 143 & 148 & 120 \\
\hline
\end{tabular}


International Journal of Advances in Scientific Research and Engineering (ijasre), Vol 7 (8), August -2021

3.5 Compressive Strength of PSA/CSA pozzolana concrete

Table 4: Compressive Strength of PSA/CSA pozzolana concrete in H20 and Sulphated curing media (N/mm2)

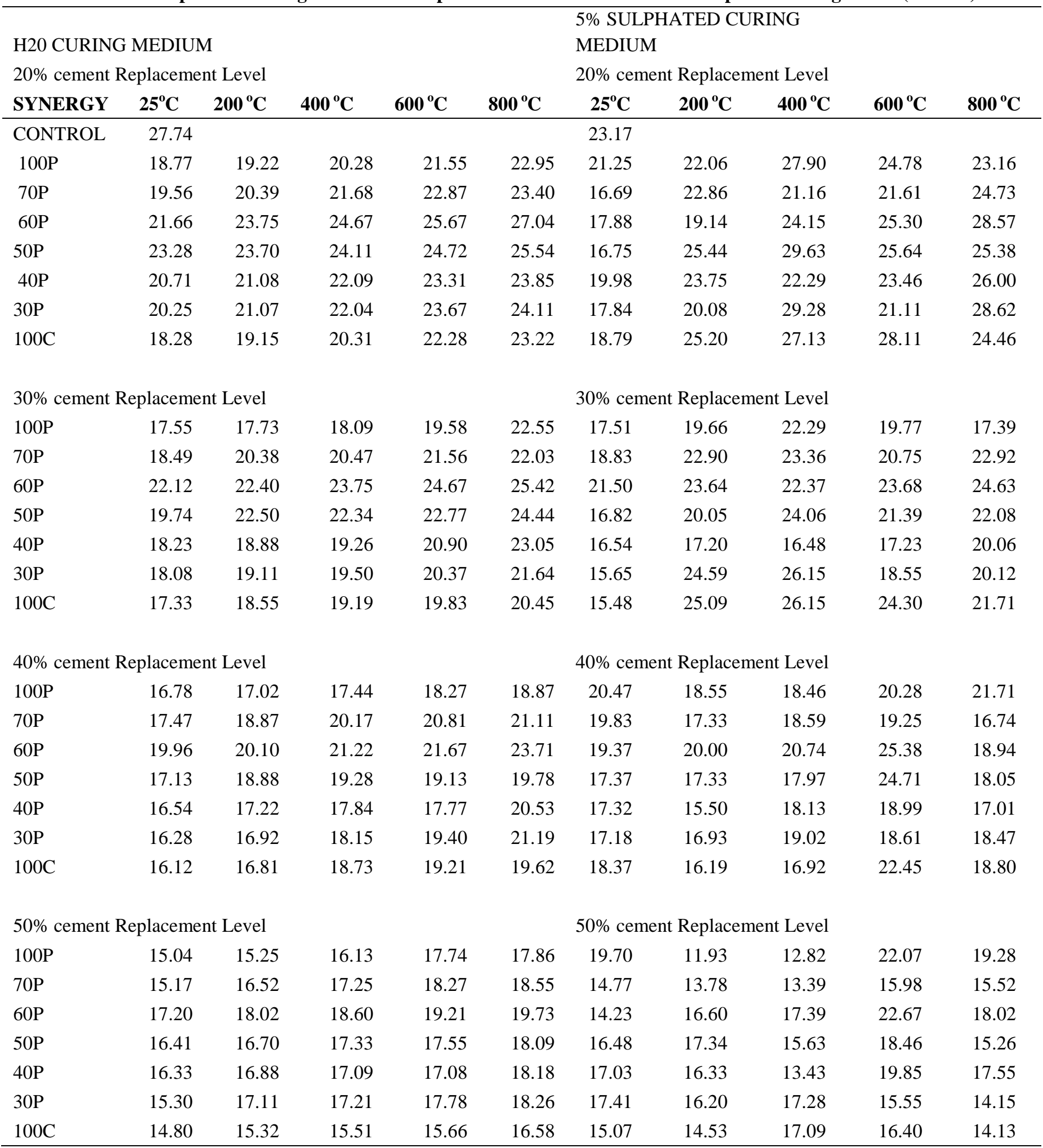

With respect to the compressive strength results as shown in Table 4, the general trend found for all cement replacement levels was quadratic in character, cresting between $70 \mathrm{p}$ and $50 \mathrm{p}$, and typically peaking at $800^{\circ} \mathrm{C}$. 
International Journal of Advances in Scientific Research and Engineering (ijasre), Vol 7 (8), August -2021

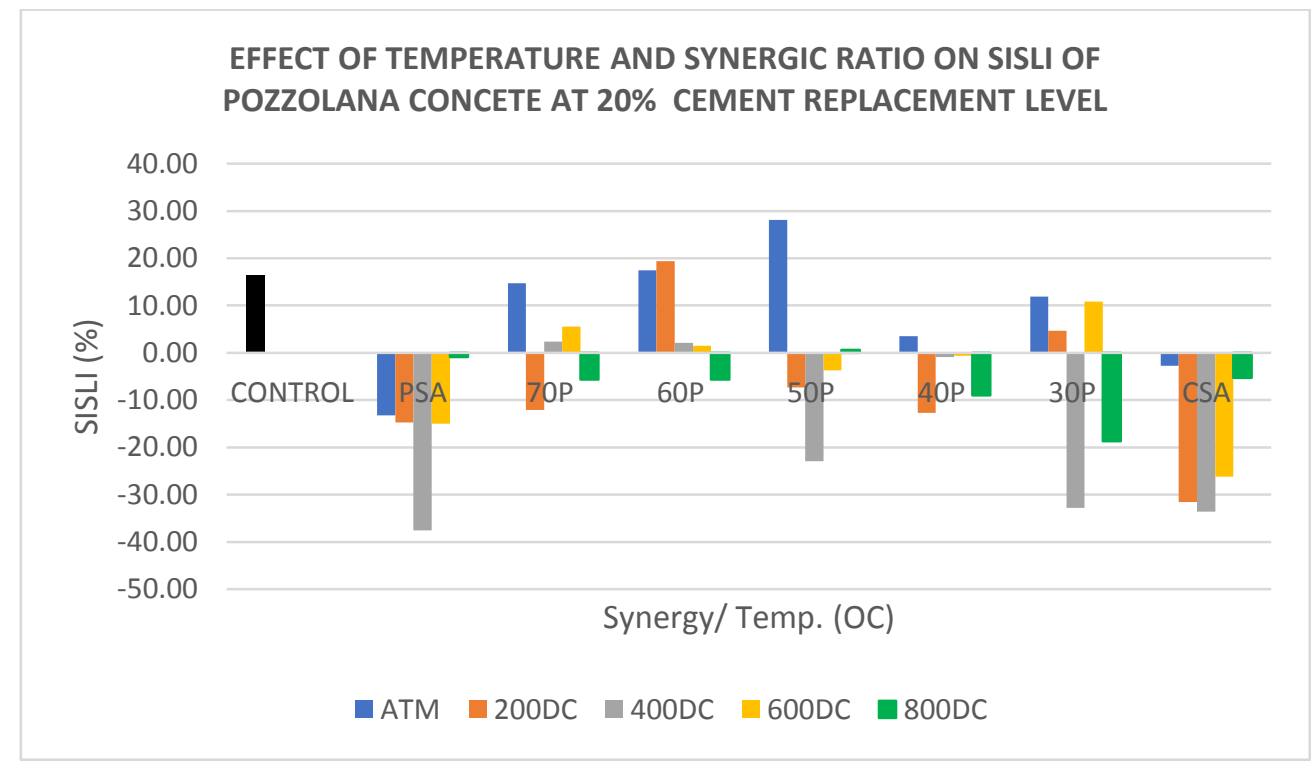

Fig. 4. 28day SISLI at $20 \%$ cement replacement level for PSA/CSA pozzolana concrete

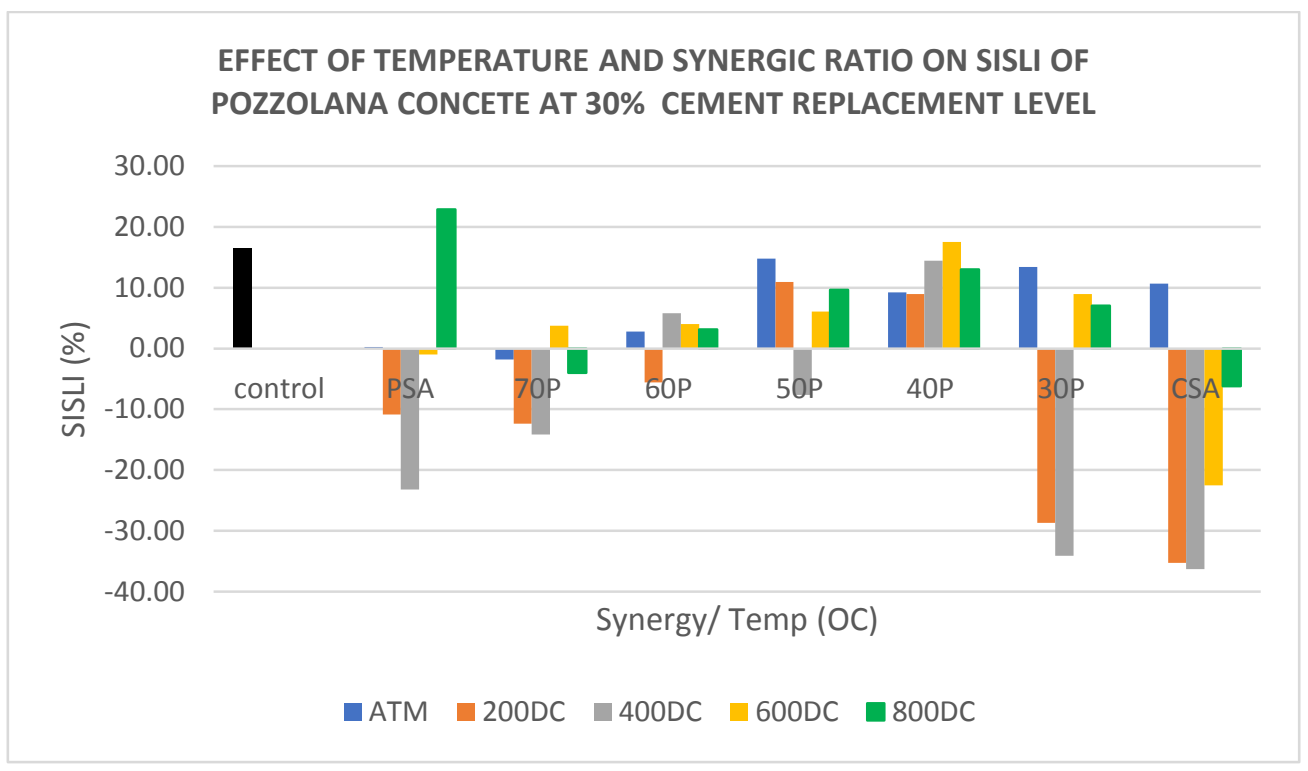

Fig. 5. 28day SISLI at 30\% cement replacement level for PSA/CSA pozzolana concrete 
International Journal of Advances in Scientific Research and Engineering (ijasre), Vol 7 (8), August -2021

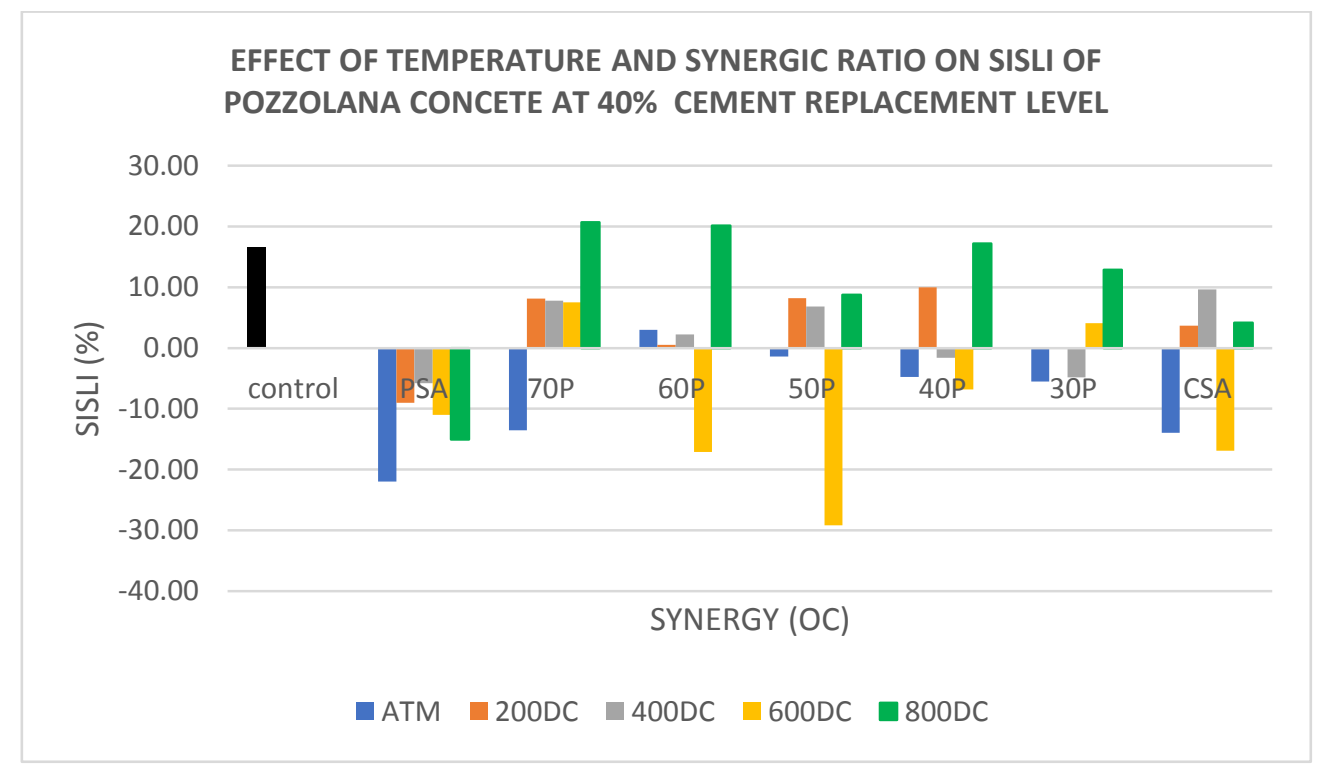

Fig. 6. 28day SISLI at $40 \%$ cement replacement level for PSA/CSA pozzolana concrete

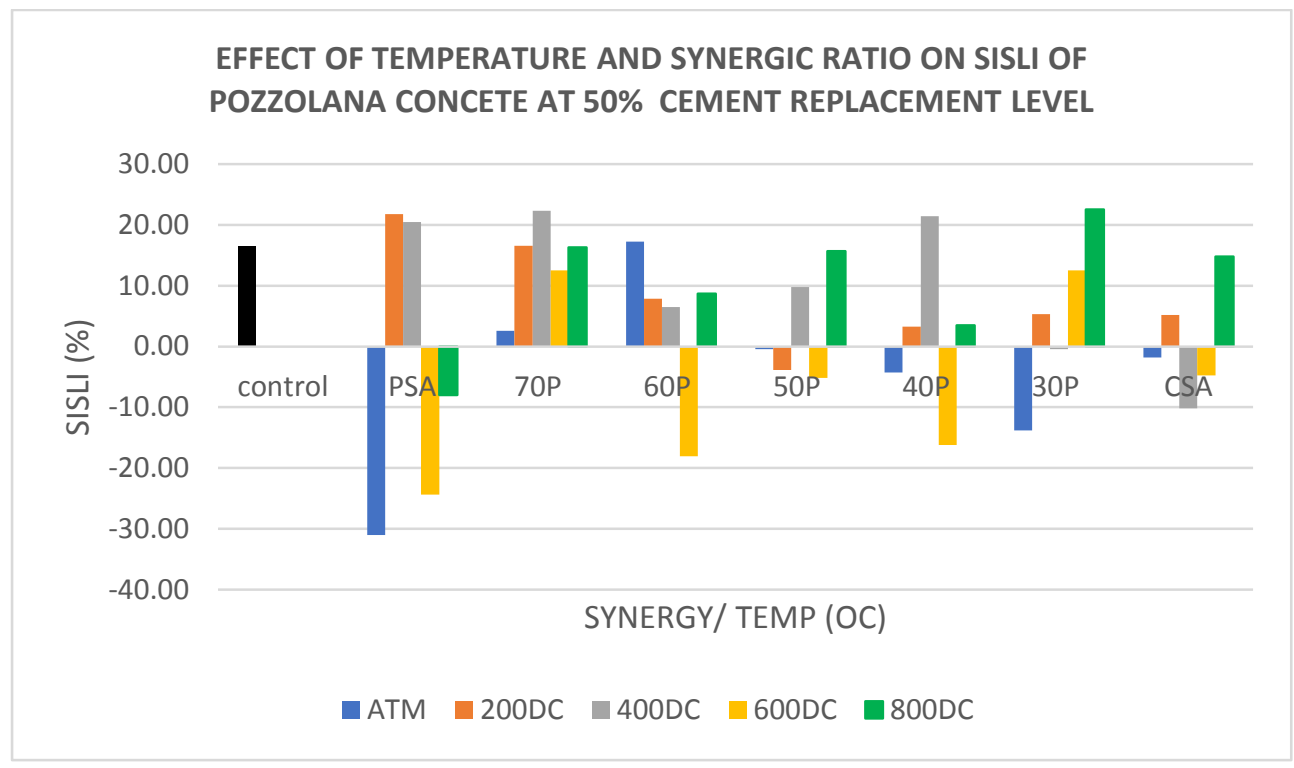

Fig. 7. 28day SISLI at 50\% cement replacement level for PSA/CSA pozzolana concrete

3.6 ANOVA and Coefficient of Regression for sulphate induced strength loss index of PSA/CSA hybrid pozzolana concrete

In order to get a better understanding of the combined effect of calcination temperature and synergistic ratio on the PSA/CSA pozzolana concrete's resistance to sulphate attack, laboratory findings were subjected to statistical analysis and modelled. 
International Journal of Advances in Scientific Research and Engineering (ijasre), Vol 7 (8), August -2021

Table 5: ANOVA and Coefficient of Regression for sulphate induced strength loss index of PSA/CSA hybrid pozzolana concrete

\begin{tabular}{|c|c|c|c|c|c|c|}
\hline$A_{-1}$ & nts & & WW & & & \\
\hline Analysis of var & al sum of $s$ & es - ' & pe III] & & & \\
\hline & Sum of & & Mean & $\mathbf{F}$ & p-value & \\
\hline Source & Squares & df & Square & Value & Prob $>$ F & \\
\hline Model & 108.65 & 13 & 8.36 & 115.26 & $<0.0001$ & significant \\
\hline${ }^{1}$ Linear Mixture & 17.97 & 2 & 8.99 & 123.94 & $<0.0001$ & \\
\hline $\mathrm{AB}$ & 0.43 & 1 & 0.43 & 5.96 & 0.0285 & \\
\hline $\mathrm{AC}$ & 0.33 & 1 & 0.33 & 4.52 & 0.0518 & \\
\hline BD & 52.81 & 1 & 52.81 & 728.32 & $<0.0001$ & \\
\hline $\mathrm{CD}$ & 0.098 & 1 & 0.098 & 1.35 & 0.2648 & \\
\hline $\mathrm{ABD}$ & 8.29 & 1 & 8.29 & 114.29 & $<0.0001$ & \\
\hline $\mathrm{BCD}$ & 11.32 & 1 & 11.32 & 156.06 & $<0.0001$ & \\
\hline $\mathrm{AD}^{2}$ & 0.31 & 1 & 0.31 & 4.27 & 0.0578 & \\
\hline $\mathrm{BD}^{2}$ & 28.45 & 1 & 28.45 & 392.29 & $<0.0001$ & \\
\hline $\mathrm{CD}^{2}$ & 0.59 & 1 & 0.59 & 8.08 & 0.0130 & \\
\hline $\mathrm{ABD}^{2}$ & 2.13 & 1 & 2.13 & 29.42 & $<0.0001$ & \\
\hline $\mathrm{BCD}^{2}$ & 10.30 & 1 & 10.30 & 142.08 & $<0.0001$ & \\
\hline Residual & 1.02 & 14 & 0.073 & & & \\
\hline Cor Total & 109.67 & 27 & & & & \\
\hline
\end{tabular}

Table 6 SISLI MODEL

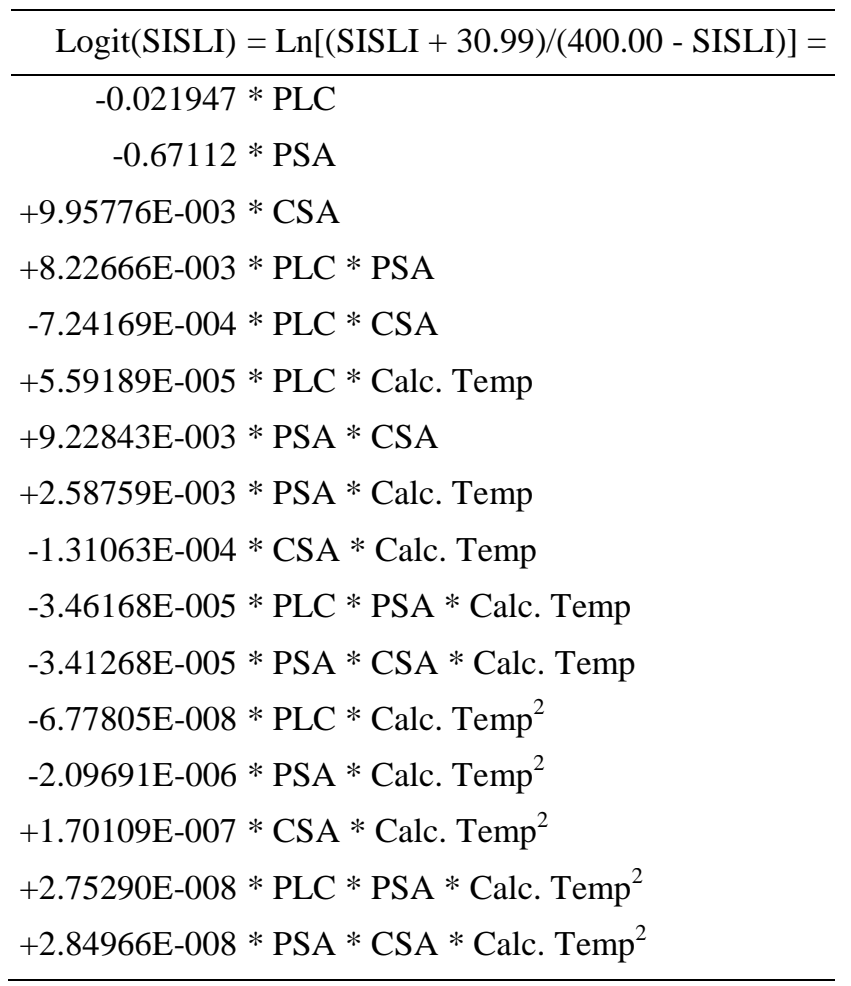


International Journal of Advances in Scientific Research and Engineering (ijasre), Vol 7 (8), August -2021

Table 7 Coefficient of Regression

\begin{tabular}{lrlr}
\hline Std. Dev. & 0.27 & R-Squared & 0.9907 \\
Mean & -2.87 & Adj R-Squared & 0.9821 \\
C.V. \% & 9.39 & Pred R-Squared & 0.8909 \\
PRESS & 11.96 & Adeq Precision & 57.634 \\
-2 Log Likelihood & -13.42 & BIC & 29.90 \\
& & AICc & 38.58 \\
\hline
\end{tabular}

Table 8 Model Coefficients and Multicollinearity Effect for the sulphate induced strength loss index of PSA/CSA hybrid pozzolana concrete.

\begin{tabular}{|c|c|c|c|c|c|c|}
\hline Component & $\begin{array}{r}\text { Coefficient } \\
\text { Estimate }\end{array}$ & df & $\begin{array}{r}\text { Standard } \\
\text { Error }\end{array}$ & $\begin{array}{r}95 \% \text { CI } \\
\text { Low }\end{array}$ & $\begin{array}{r}95 \% \text { CI } \\
\text { High }\end{array}$ & VIF \\
\hline A-PLC & -1.04 & 1 & 0.50 & -2.12 & 0.034 & 16.38 \\
\hline B-PSA & -1.97 & 1 & 0.23 & -2.47 & -1.47 & 4.93 \\
\hline C-CSA & -3.09 & 1 & 0.22 & -3.56 & -2.62 & 4.31 \\
\hline $\mathrm{AB}$ & -3.42 & 1 & 1.40 & -6.43 & -0.42 & 8.29 \\
\hline $\mathrm{AC}$ & -1.81 & 1 & 0.85 & -3.64 & 0.016 & 3.01 \\
\hline $\mathrm{BD}$ & 5.08 & 1 & 0.19 & 4.68 & 5.49 & 1.77 \\
\hline $\mathrm{CD}$ & 0.18 & 1 & 0.15 & -0.15 & 0.51 & 1.29 \\
\hline $\mathrm{ABD}$ & -11.53 & 1 & 1.08 & -13.85 & -9.22 & 1.67 \\
\hline $\mathrm{BCD}$ & -10.29 & 1 & 0.82 & -12.05 & -8.52 & 1.54 \\
\hline $\mathrm{AD}^{2}$ & -1.02 & 1 & 0.49 & -2.07 & 0.039 & 9.97 \\
\hline $\mathrm{BD}^{2}$ & -5.92 & 1 & 0.30 & -6.56 & -5.28 & 4.16 \\
\hline $\mathrm{CD}^{2}$ & 0.77 & 1 & 0.27 & 0.19 & 1.35 & 3.75 \\
\hline $\mathrm{ABD}^{2}$ & 10.33 & 1 & 1.91 & 6.25 & 14.42 & 4.42 \\
\hline $\mathrm{BCD}^{2}$ & 10.70 & 1 & 0.90 & 8.77 & 12.62 & 1.50 \\
\hline
\end{tabular}

Table 5 represents the analysis of variance and coefficient of regression for the sulphate induced strength loss index of PSA/CSA hybrid pozzolana concrete. The developed model is a combination of a quadratic mixture component and quadratic factor type model, having a significant linear mixture component as well as eleven other components integrating into a significant model having a $\mathrm{P}<<0.05$ and negating the null hypothesis. Amongst the 12 model components, $\mathrm{AC}, \mathrm{CD}$ and $\mathrm{AD}^{2}$ where not significant having $\mathrm{P}>0.05$.

The ratio of the model to total sum of squares gave a coefficient of regression of 0.9907 . accordingly, adjusted and predicted coefficients of regression was obtained as $0.9821,0.8909$, indicating a statistically sound model prediction capacity.

Standard deviation was 0.27 about a mean -2.87 , yielding an error coefficient of $9.39 \%$ (C.V). The adequate precision of the model was obtained as 57.63 , indicating that a single error could be expected for every 57.63 predictions. This is well greater than the minimum allowable associated error of 4 , hence the model indicates an adequate signal and can be used to circumnavigate the design space.

Model diagnostics as shown in Fig. 8 represents a relative distribution of the externally studentised errors. The model can hence be adopted as statistically satisfactory.

Model coefficients shown in Table 8 represents the presence of multicollinearity effect for PLC mixture component, this however does not call for concern seeing its variance inflated factor falls within the range of 0-30. All other model components have variance inflated factors less than 10 . This implies a statistical flexibility between independent variables and a good requirement for testing the effect of varying isolated factors on the response variable. 
International Journal of Advances in Scientific Research and Engineering (ijasre), Vol 7 (8), August -2021
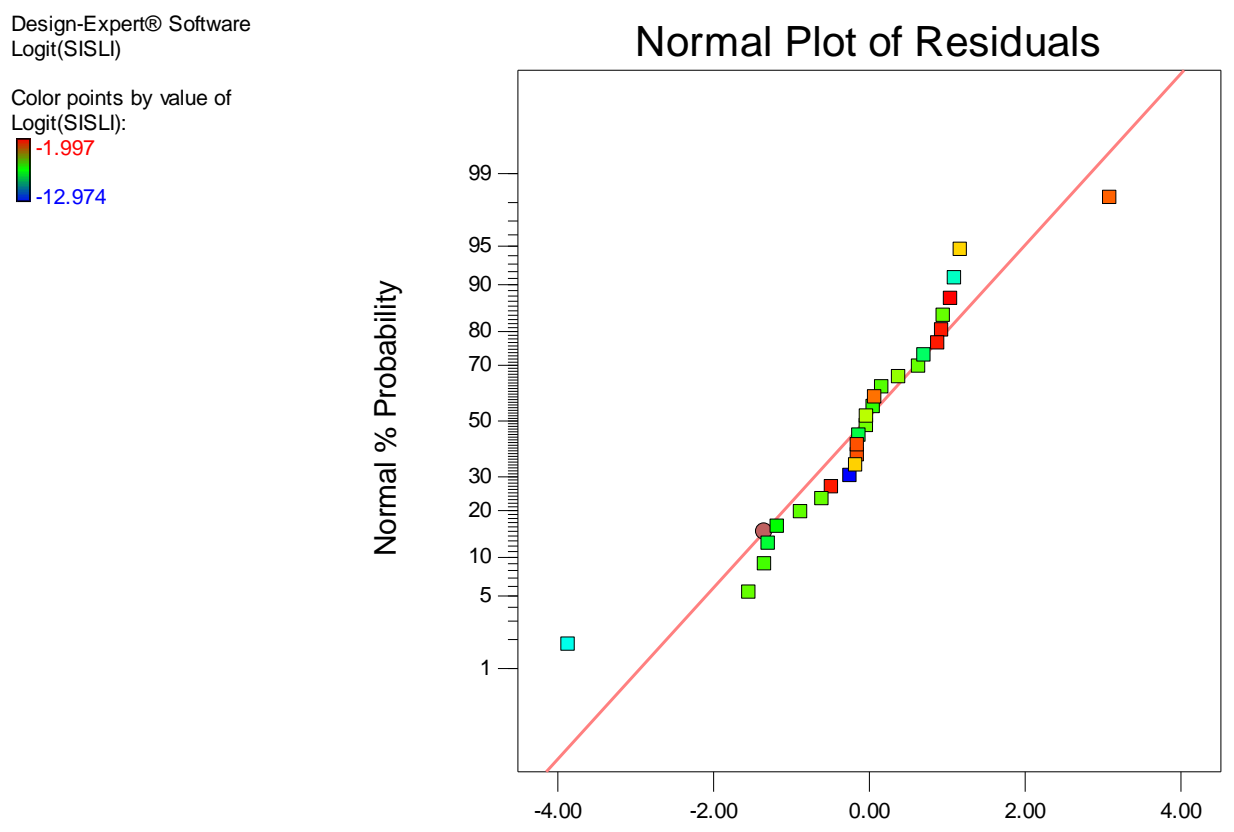

Fig. 9 Plot of externally studentized residual distribution for the sulphate induced strength loss index of PSA/CSA hybrid pozzolana concrete
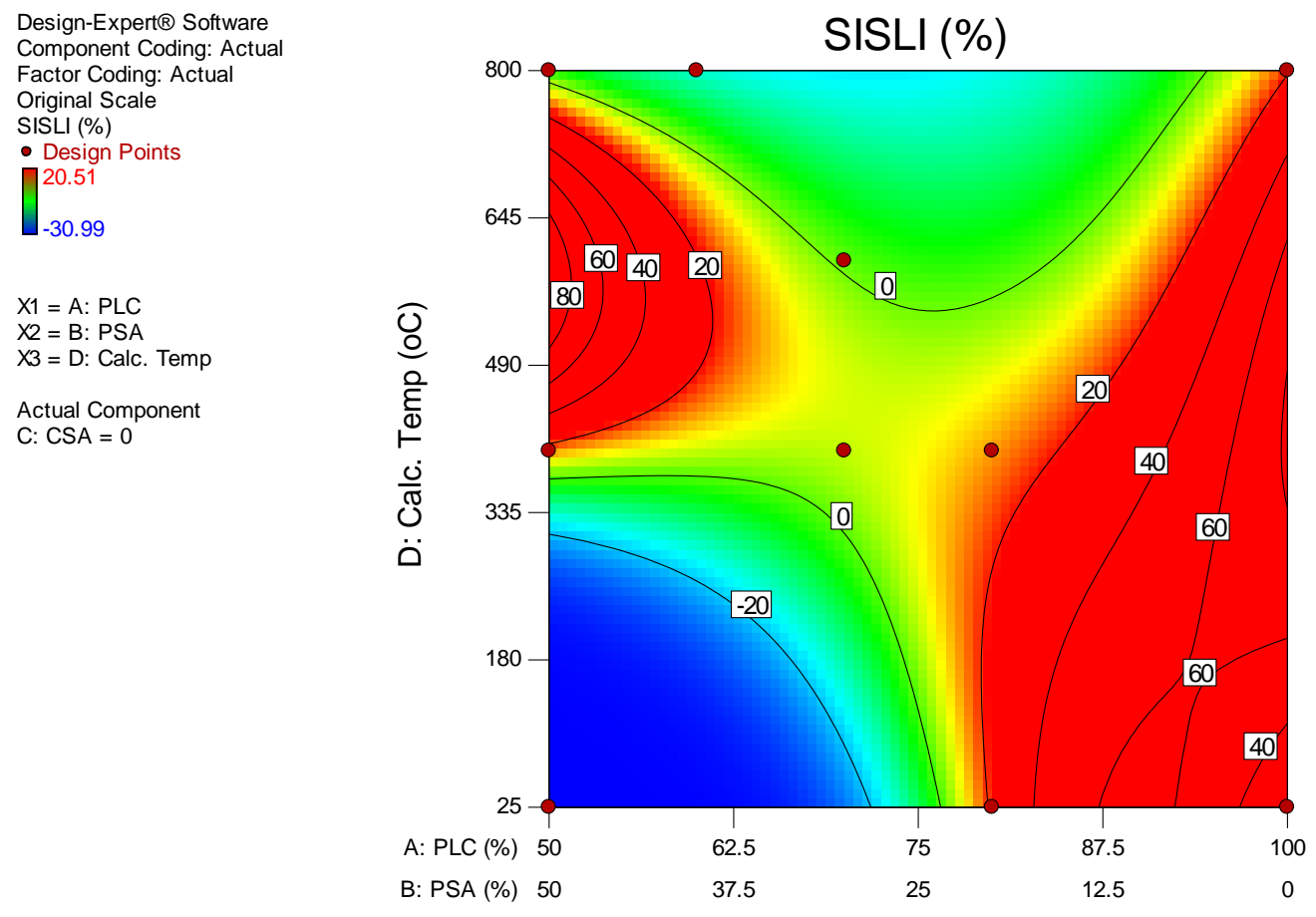
International Journal of Advances in Scientific Research and Engineering (ijasre), Vol 7 (8), August -2021

Fig. 10 Plot of model interaction at $0 \%$ CSA concentration on the sulphate induced strength loss index of PSA/CSA hybrid pozzolana concrete

Design-Expert $\circledast$ Software
Component Coding: Actual
Factor Coding: Actual
Original Scale
SISLI (\%)
- Design Points
-30.99
X1 = A: PLC
X2 = B: PSA
X3 = D: Calc. Temp
Actual Component
C: CSA = 20

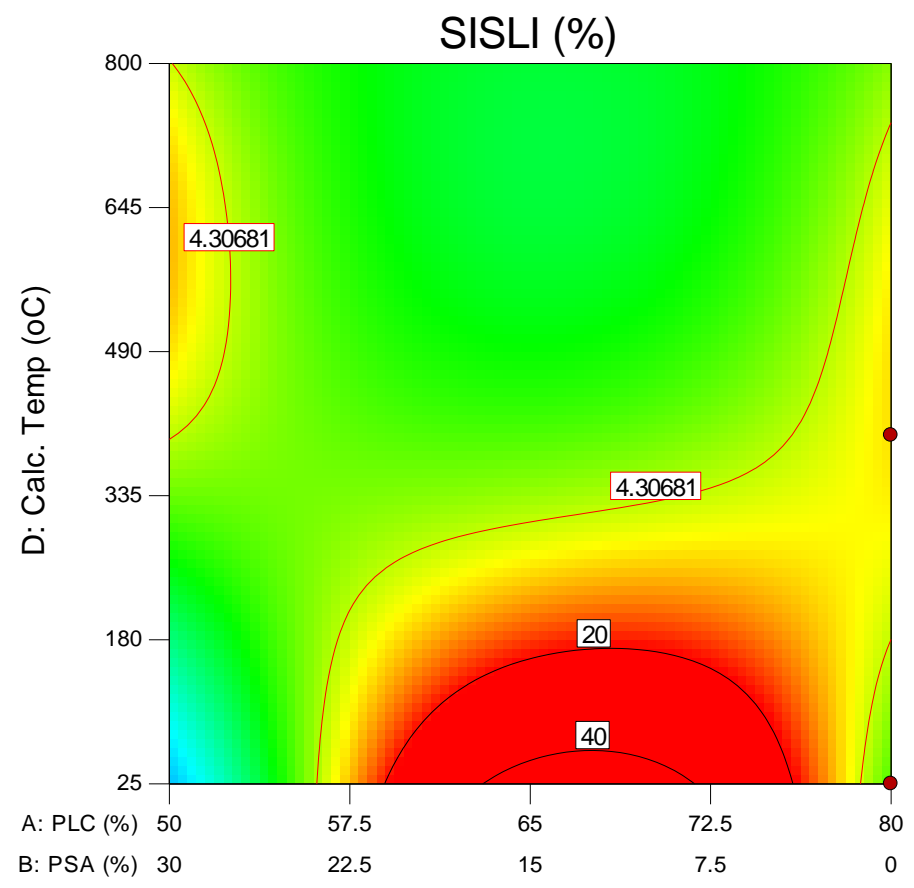

Fig. 11 Plot of model interaction at 20\%CSA concentration on the sulphate induced strength loss index of PSA/CSA hybrid pozzolana concrete

Design-Expert® Software
Component Coding: Actual
Factor Coding: Actual
Original Scale
SISLI $(\%)$
o Design Points
20.51
-30.99
X1 = A: PLC
X2 = B: PSA
X3 = D: Calc. Temp
Actual Component
C: CSA = 25

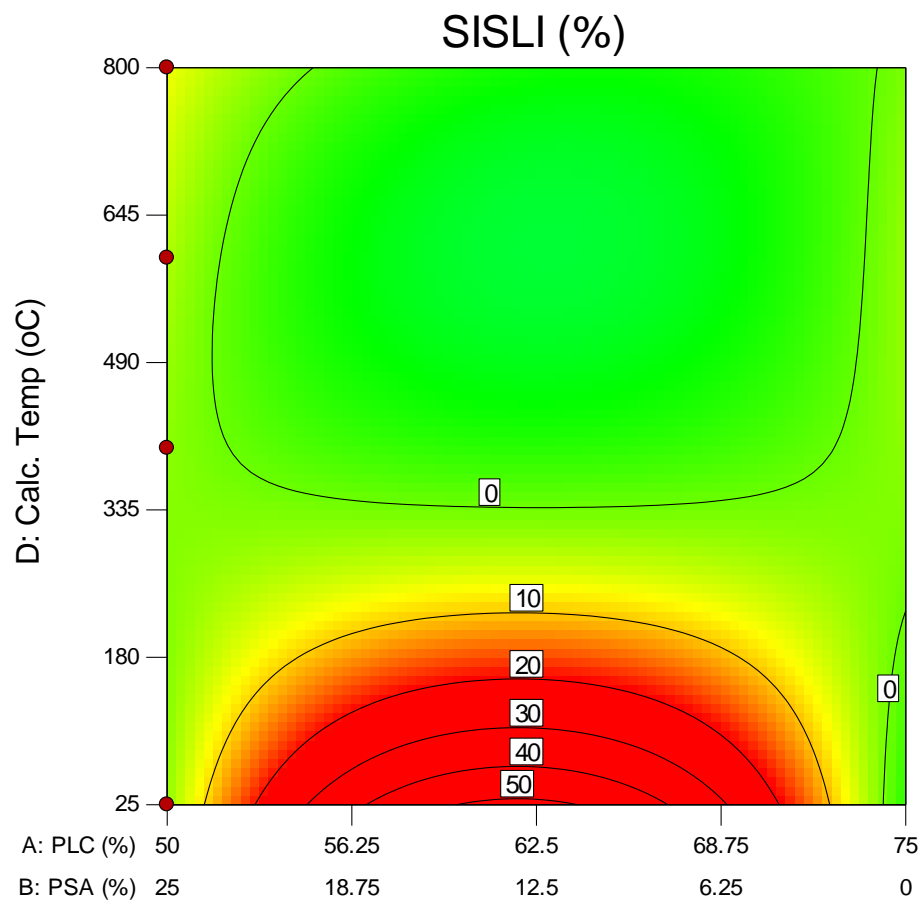


Fig. 12 Plot of model interaction at $25 \% \mathrm{CSA}$ concentration for the sulphate induced strength loss index of PSA/CSA hybrid pozzolana concrete

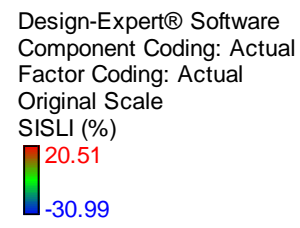

$\mathrm{X} 1=\mathrm{A}: \mathrm{PLC}$

$\mathrm{X} 2=\mathrm{B}: \mathrm{PSA}$

$\mathrm{X} 3$ = D: Calc. Temp

Actual Component C: $\mathrm{CSA}=47.5$

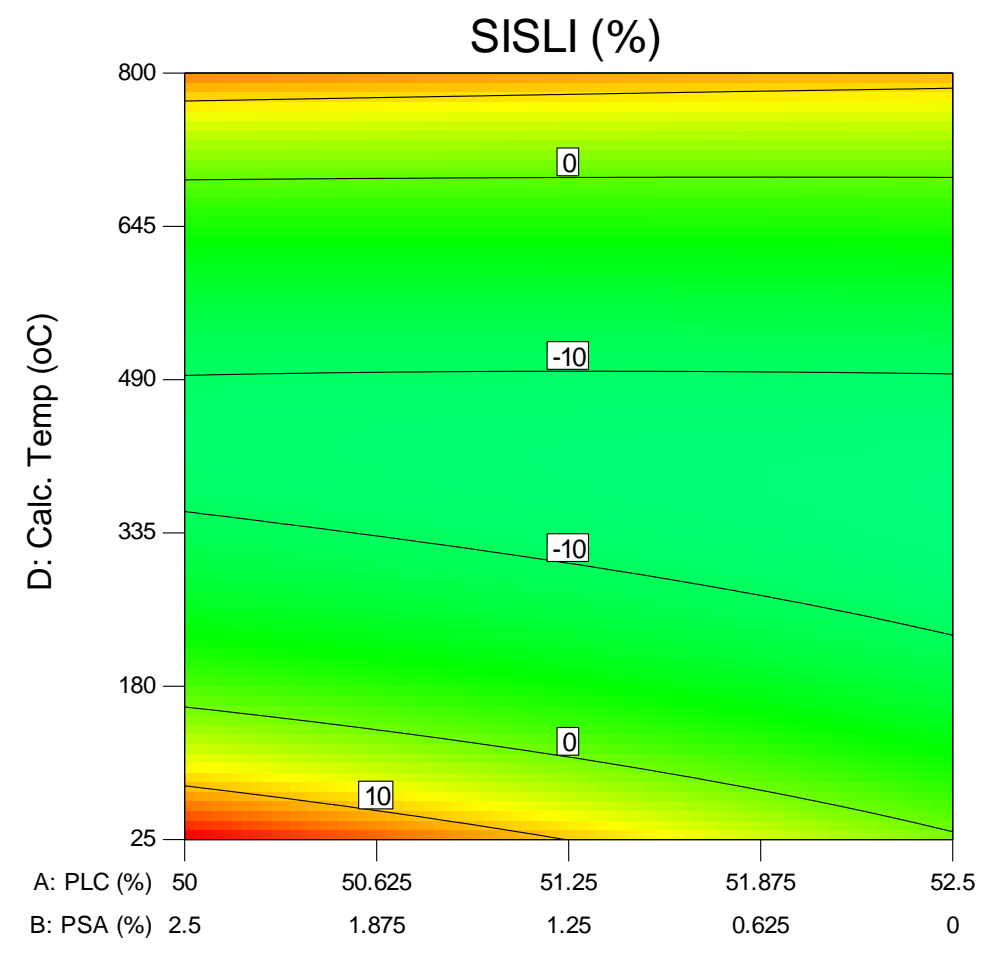

Fig. 13 Plot of model interaction 47.5\% CSA concentration for the sulphate induced strength loss index of PSA/CSA hybrid pozzolana concrete

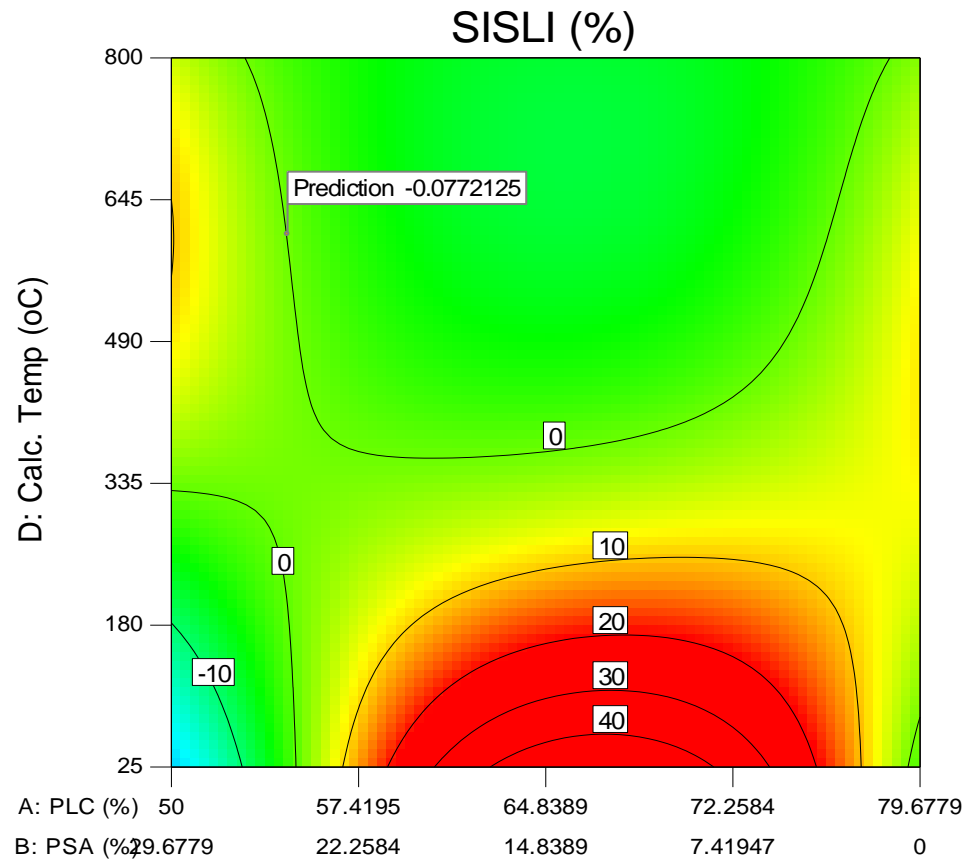


Fig. 9, Fig 10, Fig 11 and Fig. 12 are extracts from the model interaction between the mixture and process components of the SISLI model. The effect of the process factor (calcination temperature) on the SISLI of the PSA/CSA hybrid pozzolana concrete was observed to be a sagging quadratic relationship with changing trough associated with variations in the mixture configurations. Fig. 9 - 12, represents the effect of varying CSA concentration on the SISLI of PSA/CSA pozzolana concrete. At $0 \%-10 \%$ CSA content, SISLI was minimal at a PSA content ranging of $25 \% \mathrm{PSA}-50 \% \mathrm{PSA}$, at calcination temperature range of $25^{\circ} \mathrm{C}-350^{\circ} \mathrm{C}$. Also, for all temperature range at same range of CSA concentration, SISLI was minimal at PSA concentration range of $20 \%$ and $37.5 \%$. At CSA concentration range of $10-20 \%$, the calcination temperature required to minimize SISLI ranges from $25-200^{\circ} \mathrm{C}$ for PSA concentration range of $22.5 \%-30 \%$. However, a much greater spread of PSA content was accommodated at temperatures above $335^{\circ} \mathrm{C}$ as is relates to minimising SISLI of PSA/CSA hybrid pozzolana concrete. At CSA concentration of 25\% (Fig 4.101), PSA concentration is mostly irrelevant as the model commands a need for calcination temperature levels above $300^{\circ} \mathrm{C}$ in the interest of minimising SISLI. At 47.5\% CSA content (Fig. 4.102), PSA concentration and calcination temperature variations had a mean effect on the SISLI of the concrete. In essence, from the extracts (Fig. 9 - Fig.12), it can be deduced that increasing clam shell ash concentration, reduces the calcination temperature required to enhance concretes resistance to sulphate attack.

At optimization, a mixture configuration of 54.6\%PLC:25.1\%PSA:20.3\%CSA at a calcination temperature of $606.7 \%$ to yield compressive strength and SISLI of $20.8 \mathrm{~N} / \mathrm{mm} 2$ and $-0.078 \%$ which are $75 \%$ and $-0.47 \%$ of plain concrete's values of $27.74 \mathrm{~N} / \mathrm{mm} 2$ and $16.47 \%$

\subsection{CONCLUSION}

- Calcination temperature is linearly related with fineness and compressive strength with a direct proportionality

- Synergistic ratio is cubically related with slump and compressive, cresting around 60PSA/40CSA and troughing around 30PSA/70CSA

- All synergies where observed to be better in compressive strength when compared to the primary pozzolans and primarily due to the effect of calcination

- $\quad$ Cement replacement level was seen to be linearly related with compressive strength with a inverse proportionality.

- Synergistic ratio had a quadratic relationship with SISLI which tends to change its form relative to a calcination temperature of $335^{\circ} \mathrm{C}$. below $335^{\circ} \mathrm{C}$ the relationship was of a hugging quadratic form and change to a sagging quadratic curve at temperature above $335^{\circ} \mathrm{C}$. In both cases, crests and troughs were observed around a synergistic ratio of 60PSA/40CSA

\section{Declaration of competing interest}

We undertake not to engage in any financial, commercial, legal, or professional dealings with other organizations or the people we worked with that would have an impact on this research.

\section{REFERENCES}

1. Tayeh, B. A., Hasaniyah, M. W., Zeyad, A. M., Awad, M. M., Alaskar, A., Mohamed, A. M., \& Alyousef, R. (2020). Durability and mechanical properties of seashell partially-replaced cement. Journal of Building Engineering, $31,101328$.

2. Richardson, A. E., \& Fuller, T. (2013). Sea shells used as partial aggregate replacement in concrete. Structural Survey.

3. Umoh, A. A., \& Olusola, K. O. (2013). Performance of periwinkle shell ash blended cement concrete exposed to magnesium sulphate. Civil Engineering Dimension, 15(2), 96-101.

4. Neville, A. M. (1995). Properties of concrete (Vol. 4). London: Longman.

5. Abowei, J. F. N., \& Ezekiel, E. N. (2013). Potential and uses of fish products and other aquatic animals. Scientia Agriculturae, 3(3), 70-81.

6. Taylor, H. F. (1997). Cement chemistry (Vol. 2, p. 459). London: Thomas Telford.

7. T.G. Nijland, J.A. Larbi, in Non-Destructive Evaluation of Reinforced Concrete Structures: Deterioration Processes and Standard Test Methods, 2010

8. Ian Sims, Bev Brown, in Lea's Chemistry of Cement and Concrete (Fourth Edition), 1998

9. D. Breysse, in Non-Destructive Evaluation of Reinforced Concrete Structures: Deterioration Processes and Standard Test Methods, 2010

10. Daman K. Panesar, in Developments in the Formulation and Reinforcement of Concrete (Second Edition), 2019

11. Soroka, I., \& Setter, N. (1980). Effect of mineral fillers on sulfate resistance of Portland cement mortars. In Durability of building materials and components. ASTM International. 
12. Sadiq, O.M., Akpan, A.J., and Musa, A.O., Strength Evaluation of Concrete in Chemically Aggressive Environment, Nigeria Society of Engineers Technical Transaction, 31(2), 1996, pp. 80-86.

13. Khatib, J. M., \& Hibbert, J. J. (2005). Selected engineering properties of concrete incorporating slag and metakaolin. Construction and building materials, 19(6), 460-472.

14. Bhatty, J.I. and Taylor, P.C., Sulphate Resis-tance of Concrete using Blended Cement or Supplementary Cementitious Materials, PCA R\&D Serial No. 2916a, Portland Cement Association, USA, 2006.

15. Lertwattanaruk, P., Makul, N., \& Siripattarapravat, C. (2012). Utilization of ground waste seashells in cement mortars for masonry and plastering. Journal of environmental management, 111, 133-141.

16. Soltanzadeh, F., Emam-Jomeh, M., Edalat-Behbahani, A., \& Soltan-Zadeh, Z. (2018). Development and characterization of blended cements containing seashell powder. Construction and Building Materials, 161, 292-304.

17. Kamau, J., Ahmed, A., \& Ngong, K. (2018). Sulfate resistance of rice husk ash concrete.

18. BS EN 197-1:2000 'Cement. Composition, specifications and conformity criteria for common cements. British Standards Institute, London, United Kingdom.

19. IS 4031, 1996,' Methods of physical tests for hydraulic cement - part 4 determination of consistency of standard cement paste' Indian Standard.

20. BS 4450 - 3, (1978) 'Methods of Testing Cement. Physical Tests.' British Standards Institute, London, United Kingdom

21. BS EN 12350-2, (2009) 'Testing fresh concrete - Slump-test', British Standards Institute, London, United Kingdom.

22. BS EN 12390 - 3, (2009), 'Testing hardened concrete - Compressive strength of test' British Standards Institute, London, United Kingdom.

23. BS EN 12390 - 8 (2009), 'Testing hardened concrete - Depth of penetration of water under pressure' British Standards Institute, London, United Kingdom.

24. British Standard 812 Part 1- 75 'Methods of Determination of Particle Size and Shape' British Standards Institute, London, United Kingdom.

C.Author: Happinessmac-eteli@ndu.edu.ng

\section{CRediT authorship contribution statement}

- Mac-Eteli, D. Happiness: Investigation, Writing - original draft.

- Overo E. Kenneth: Investigation, Writing - original draft. 